Çukurova Üniversitesi Mühendislik Fakültesi Dergisi, 36(1), ss. 105-119, Mart 2021

Cukurova University Journal of the Faculty of Engineering, 36(1), pp. 105-119, March 2021

\title{
Bakır Anot Çamurundan Bakırın Liçinde Düşük Ötektik Noktalı Çözücü Kullanımının Araştırılması
}

\author{
Mehmet Ali TOPÇU* ${ }^{* 1}$, Volkan KALEM², Aydın RÜŞEN ${ }^{1}$ \\ ${ }^{1}$ Karamanoğlu Mehmetbey Üniversitesi, Mühendislik Fakültesi, Metalurji ve Malzeme \\ Mühendisliği Bölümü, Karaman \\ ${ }^{2}$ Konya Teknik Üniversitesi, Mühendislik ve Doğa Bilimleri Fakültesi, Metalurji ve Malzeme \\ Mühendisliği Bölümü, Konya
}

Geliş tarihi: 30.12 .2020

Kabul tarihi: 31.03 .2021

$\ddot{O} z$

Bu çalışmada, pirometalurjik yöntemle metalik bakır üretiminin elektrokazanım aşamasında ortaya çıkan anot çamurundan bakır geri kazanımı üzerine çevre ve insan sağlığına duyarlı düşük ötektik noktalı çözücü (DES) kullanımı araştırılmışıı. Taguchi optimizasyon yöntemi kullanılarak liç sıcaklığı, liç süresi ve katı/sıvı oranı deneysel parametrelerin bakır geri kazanımı üzerine etkisi incelenmiştir. Kolin klorür $(\mathrm{ChCl})$ ve ürenin 1:2 molar oranda karıştırılmasıyla hazırlanan DES çözücüsü ile yapılan liç işlemleri sonunda optimum şartlar; $95{ }^{\circ} \mathrm{C}$ 'liç sıcaklığı, 2 saat liç süresi ve $1 / 20$ katı/sıvı oranı olarak belirlenmiş ve bu şartlarda \%98 bakır geri kazanımı elde edilmiştir. Yapılan bu çalışma ile ChCl-üre karışımıyla hazırlanan DES çözücüsünün anot çamurundan bakır geri kazanımı için çevreci bir çözücü adayı olabileceği ortaya konulmuştur.

Anahtar Kelimeler: Bakır anot çamuru, Düşük ötektik noktalı çözücü, Metal geri kazanımı, Solvometalurji

\section{Investigation of Use of Deep Eutectic Solvent on Copper Leaching from Copper Anode Slime}

\begin{abstract}
In this study, use of environmentally and human health sensitive solvent, called deep eutectic solvent (DES), was investigated for copper recovery from anode slime which was produced during electrorefining stage of the metallic copper production by pyrometallurgical method. The effect of experimental parameters was investigated using the Taguchi optimization method. At the end of the leaching process with DES solvent prepared by mixing $\mathrm{ChCl}$ and urea in 1:2 molar ratio, optimum conditions were determined as; $95^{\circ} \mathrm{C}$ leaching temperature, 2 hours leaching time and 1/20 solid/liquid ratio and $98 \%$ copper recovery was obtained under this condition. With this study, it has been revealed that DES prepared by $\mathrm{ChCl}$-urea mixture can be an environmentally friendly solvent candidate for copper recovery from anode slime.
\end{abstract}

Keywords: Copper anode slime, Deep eutectic solvent, Metal recovery, Solvometallurgy

"Sorumlu yazar (Corresponding author): Mehmet Ali TOPÇU, topcumali@kmu.edu.tr 


\section{GíRiș}

Sülfürlü bakır cevherleri dünya bakır rezervlerinin yaklaşık \%80'ini içermektedir. Kalkopirit ise sülfürlü cevherler içerisinde yeryüzünde bol bulunan bir bakır mineralidir ve pirometalurjik yöntemle bakır üretiminin ana kaynağıdır [1] Günümüzde, kalkopirit mineralinden metalik bakır üretimi için kullanılan endüstriyel yöntem ufalama, flotasyon, eritme, dönüştürme, ateşle rafinasyon ve elektro rafinasyon aşamalarını içeren piroelektrometalürji yöntemdir [2]. Elektro rafinasyon aşamasının ana amacı, bakırın saf olmayan döküm anotlardan elektrokimyasal olarak çözündürülmesi ve ardından bakır iyonlarının katot yüzeyine taşınarak yüksek saflıkta bakır katotları elde edilmesidir. Bakır çözündürülmesi için uygulanan potansiyel altında, bakırın potansiyelinden daha düşük indirgeme potansiyeline sahip doğal safsızlıklar (Se, Te, As, Sb, Pb, Sn, Ag, Au, Pt ve Pd) da elektrolitik çözeltiye serbest olarak bırakılır [3]. Bu safsızlıkların çoğu daha büyük yoğunluğa sahiptir ve anot çamuru adı verilen yan ürün meydana getirerek elektrorafinasyon havuzunun tabanına yerleşme eğilimindedir. Meydana gelen anot çamurunun kimyasal kompozisyonu ve mineralojik yapısı safsızlıkların miktarına bağlıdır. Her bir ton bakır katot üretimi için yaklaşık olarak $20 \mathrm{~kg}$ anot çamuru meydana gelmektedir [4].

Bakır anot çamurları kayda değer miktarda $\mathrm{Cu}, \mathrm{Pb}$, $\mathrm{Se}, \mathrm{Te}, \mathrm{Au}, \mathrm{Ag}$ ve platin grubu ( $\mathrm{Pt}$ ve $\mathrm{Pd})$ metallerini içerdiğinden değerli metallerin geri kazanımında önemli bir ikincil kaynak olarak görülmektedir. Bununla birlikte, arsenik ve kadmiyum gibi elementlerin varlığı nedeniyle tehlikeli atık olarak listelenen suda çözünmeyen bir yan üründür. Bakır anot çamurlarındaki bakır, doğrudan pirometalurjik yöntemin herhangi bir aşamasında kullanılabilir veya bu atıktan doğrudan metal geri kazanımı yapılabilir. Antimon, arsenik ve kurşun gibi bakır anot çamurunun ihtiva ettiği temel metaller bakıra nazaran daha az konsantrasyona sahiptir. Ancak bu metallerin çevre üzerindeki etkileri göz önünde bulundurulduğunda geri kazanımları gerekli hale gelmiştir. Ayrıca, bakır anot çamurları enerji sektöründe stratejik öneme sahip Se ve Te gibi metaller için ana kaynak olarak görülmektedir [5].
Günümüze kadar bakır anot çamurlarından değerli metallerin geri kazanımında pirometalurjik, hidrometalurjik veya piro/hidro-metalurjik yöntemlerden oluşan birçok süreç geliştirilmiştir. Bakır anot çamurundan değerli metallerin geri kazanım süreçlerinin seçimi numunenin bakır içeriğine bağlı olmaktadır. Değerli metallerin bakır anot çamurlarından metalürjik yöntemlerle geri kazanımında genellikle asit liçi [6,7] oksidatif liç $[8,9]$ mikrodalga ve ultrason destekli asit liçi $[10,11]$, alkali füzyon yöntemi $[12,13]$ ve yenilikçi bir yaklaşım olan iyonik sıvıların sulu çözeltileri $[14,15]$ kullanılmıştır. $\mathrm{Bu}$ yöntemlerde fazla miktarda asit kullanılması, liç işlemlerinde geleneksel yöntemle ilave ekipman kullanılması ve bazı çözeltilerin maliyeti nedeniyle bakır anot çamurlarından metal geri kazanımı için ucuz, güvenli ve çevre ile uyumlu çözücü arayışı devam etmektedir.

Solvo-metalurji sulu çözeltiler yerine moleküler organik çözücüler, iyonik sıvılar ve d düşük ötektik noktalı (Deep eutetic solvent, DES) gibi sulu olmayan çözücüler kullanan yeni bir ekstraktif metalurji dalıdır [16]. Solvometalurji yöntemi, pirometalurji yöntemine nazaran daha az enerji tüketen bir yöntemdir ve hidrometalurji yöntemine göre daha fazla seçicilik sağladığı vurgulanmıştır [17]. Düşük ötektik noktalı ötektik karışım oluşturmak için hidrojen bağı etkileşimi ile birbirleriyle ilişkilendirilebilen genellikle iki veya üç ucuz ve güvenli bileşenlerden oluşur. DES'ler organik çözücülerle kıyaslandığında düşük buhar basınc1, tutuşmama, kolay geri dönüşüm gibi özellikleri ile birlikte biyolojik olarak parçalanabildikleri için çevre duyarlı çözücü olarak birçok alanda kullanımı gerçekleştirilmiştir [18]. Ayrıca literatürde yer alan bir çalışmada [19] farklı bileşenlerle hazırlanan DES'lerin farklı metal oksitleri çözebildiği vurgulanmıştır. Örneğin $\mathrm{ChCl}$ ve fenilpropionik ile hazırlanan DES içerisinde $\mathrm{CuO}$ bileşiğinin çözünürlük oranı $(0,473 \mathrm{~mol} / \mathrm{L})$ oldukça yüksek iken, $\mathrm{ChCl}$ ve oksalik asitle hazırlanan DES içerinde $\mathrm{CuO}$ bileşiğinin çözünürlük oranı oldukça düșüktür (0,071 mol/L). Abbott ve arkadaşları (2006b) yaptığı başka bir çalışmada, $\mathrm{ChCl}$ ve üre ile hazırlanan DES'in içerisinde $\mathrm{Cu}_{2} \mathrm{O}, \mathrm{PbO}_{2}$ ve $\mathrm{ZnO}$ 
bileşiklerinin çözünürlük değerleri sırasıyla 8725 ppm, 9157 ppm ve 8466 ppm iken, $\mathrm{Al}_{2} \mathrm{O}_{3}$ bileşiğinin çözünürlük değerinin $<1 \mathrm{ppm}$ ve $\mathrm{CaO}$ bileşiğinin çözünürlük değerinin 6 ppm sınırında olduğu belirtilmiştir. Bu yüzden uygun bileşenlerle hazırlanacak olan DES'lerin metal çözündürme işlemlerinde seçicilik sağlayacağı vurgulanmıştır [20].

$\mathrm{Bu}$ özelliklerinde dolayı, son yıllarda metal kaynaklarından değerli metallerin geri kazanımında çevre duyarlı çözücü olarak kullanılan DES'ler, elektrik ark fırını tozu [21,22], çinko liç atığı [23,24] ve ömrü tamamlanmış lityum iyon bataryalarından [24,25] metal geri kazanımındaki verimlilikleri araştırılmıştır.

$\mathrm{Bu}$ çalışmada bakır anot çamurundan bakır geri kazanımı için yeni bir yöntem olan solvo-metalurji yöntemi önerilmektedir. Ayrıca, bakır geri kazanımı için metal kaynağı olarak kullanılan anot çamurunun kimyasal ve mineralojik karakterizasyonu ve liç sürecinin optimizasyonunu amaçlanmıştır.

\section{MATERYAL VE METOT}

\subsection{Materyal}

$\mathrm{Bu}$ çalışmada kullanılan bakır anot çamuru Denizli'de faaliyet gösteren Er-Bakır firmasında temin edilmiştir. Kolin klorür $\left(\mathrm{C}_{5} \mathrm{H}_{14} \mathrm{ClNO},>\% 98\right)$ Merck firmasından, üre $\left(\mathrm{CO}\left(\mathrm{NH}_{2}\right)_{2},>99 \%\right)$ ise Petkim firmasından ticari olarak satın alınmıştır. Liç solüsyonları seyreltmek için kullanılan $\mathrm{HCl}$ asit (\%36,5-38) Sigma Aldrich'den tedarik edilmiştir

\subsection{Anot Çamurunun Karakterizasyonu}

Toz halinde Er-Bakır A.Ş'den temin edilen bakır anot çamurunun kimyasal analizi endüktif eşleşmiş plazma kütle spektrometresi (ICP-MS) ve kupelasyon yöntemi ile gerçekleştirilmiştir. Kimyasal analizi yapılan bakır anot çamurunun mineralojik yapısının belirlenmesi için Bruker D8 Advance model X-Işını Kırınımı (XRD) cihazı ve alan emisyonlu taramalı elektron mikroskobu (FE-SEM) cihazı kullanılmıştır. Bakır anot çamurunun SEM analizlerinde, her hangi bir kaplama yapılmaksızın enerji dağılımlı X-Ray (EDS) spektroskopili Hitachi SU5000 model SEM cihazı kullanılmıştır. Ayrıca, liç işlemleri sonrası elde edilen liç atığının kimyasal ve mineralojik yapısı SEM/EDS yöntemi ile incelenmiştir.

\subsection{Düşük Ötektik Noktalı Çözücünün Hazırlanması}

Liç deneylerinde kullanılan düşük ötektik noktalı çözücü ticari olarak satın alınan $\mathrm{ChCl}$ ve ürenin ilave bir saflaştırma ve kurutma işlemi yapılmaksızın önceki çalışmalarda belirtildiği üzere [22,27] 1:2 molar oranda karıştırılmasıyla elde edilmiştir. Erime sıcaklıkları sırasıyla $302{ }^{\circ} \mathrm{C}$ ve $133{ }^{\circ} \mathrm{C}$ olan $\mathrm{ChCl}$ ve üre ile hazırlanan DES için bileşenlerin bir araya getirilmesi yeterli iken, çözücünün oluşumunu hızlandırmak, homojen ve renksiz bir sıvı elde etmek için $80^{\circ} \mathrm{C}$ ' de bir beher içinde manyetik karıştırıcıda karıştırılmıştır. Elde edilen çözelti daha sonra liç deneylerinde kullanılmak üzere ağzı kapalı şişede muhafaza edilmiştir. Düşük ötektik noktalı çözücünün hazırlanması şematik olarak Şekil 1'de gösterilmektedir.

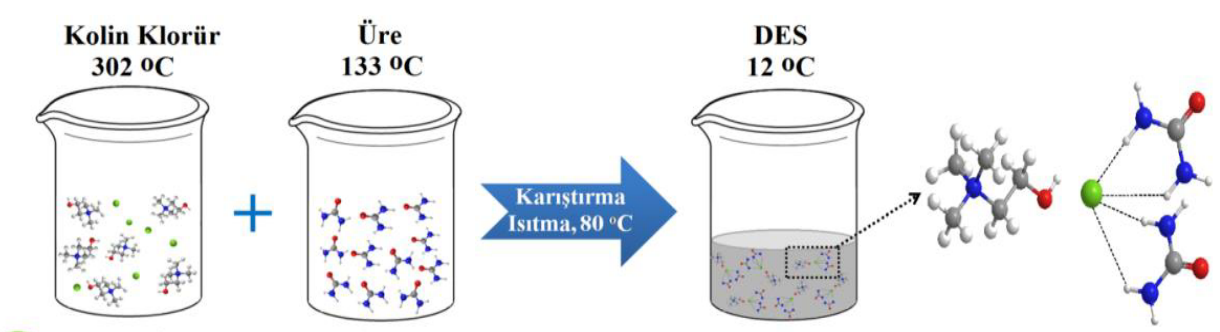

Klor Nitrojen Oksijen Hidrojen

Şekil 1. Düşük ötektik noktalı çözücünün hazırlanması 


\subsection{Liç İşlemleri}

Anot çamurundan bakır liçi için gerçekleştirilen liç deneyleri, ceketli ısıtıcı içerisinde yerleştirilmiş üç boyunlu cam içerisinde gerçekleştirilmiştir. Isıtıcı $\pm 0,5^{\circ} \mathrm{C}$ duyarlılığa sahip bir sicaklık sensörü ile kontrol edilmiştir. Liç deneyleri sırasında manyetik karıştırıcının hızı 600 devir/dk ve liç çözeltisinin hacmi $50 \mathrm{~mL}$ sabit değerlerde tutulmuştur. Solvometalurji çalışmalarında, metal geri kazanımını etkileyen en önemli parametre liç reaktifinin konsantrasyonudur. Düşük ötektik noktalı çözücülerin doğaları gereği iki bileşiğin belirli stokiometrik oranlarda karıştırılmasıyla elde edildiğinden, bu çalışma kapsamındaki deneylerde liç kimyasalının konsantrasyonu $\mathrm{ChCl}$-üre 1:2 molar oranı sabit tutularak diğer parametrelerin bakır anot çamurundan bakır geri kazanımı üzerine etkisi incelenmiştir. ChCl-üre karışımı oda sıcaklığında sıvı formda olsa da oldukça viskoz bir yapıya sahiptir. Liç deneylerinde sıcaklık yüksek tutularak $\left(75-95{ }^{\circ} \mathrm{C}\right)$ viskozitenin olumsuz etkisi bertaraf edilmiştir. Ortogonal deney düzeneği takip edilerek anot çamurundan bakır geri kazanımı üzerine etkisi incelenen parametreler ve seviyeleri Çizelge 1'de verilmektedir.

Çizelge 1. Anot çamurundan bakır liçinde incelenen deneysel parametreler ve seviyeleri

\begin{tabular}{|l|c|c|c|}
\hline \multirow{2}{*}{ Parametreler } & \multicolumn{3}{|c|}{ Seviyeler } \\
\cline { 2 - 4 } & 1. Seviye & 2. Seviye & 3. Seviye \\
\hline Liç Sıcaklığ $\left({ }^{\circ} \mathrm{C}\right)$ & 75 & 85 & 95 \\
\hline Liç Süresi (saat) & 1 & 2 & 4 \\
\hline Katı/S1v1 Oranı (g/L) & $1 / 10$ & $1 / 15$ & $1 / 20$ \\
\hline
\end{tabular}

Liç deneylerinden sonra katı/sıvı ayrımı vakum pompası yardımıyla gerçekleştirilmiştir. Düşük ötektik noktalı çözücünün viskoz bir yapıya sahip olması nedeniyle, süzme işlemleri sırasında ayrımı kolaylaştırmak için sıcak hava kullanılmıştır. Erime sıcaklıkları sirasıyla $302{ }^{\circ} \mathrm{C}$ ve $133{ }^{\circ} \mathrm{C}$ olan $\mathrm{ChCl}$ ve üre ile hazırlanan DES için bileşenlerin oda sıcaklığında bir araya getirilmesi yeterli iken, çözücünün oluşumunu hızlandırmak ve homojen bir sıvı elde etmek için $80{ }^{\circ} \mathrm{C}$ 'de bir beher içinde manyetik karıştırıcıda karıştırılmıştır.

Daha sonra, yeteri kadar seyreltilmiş liç çözeltisi Agilent Technologies marka indüktif eşleşmiş plazma atomik emisyon spektroskopisi (ICP-OES, 720 Axial) cihazı kullanılarak analiz edilmiştir. Liç çözeltisi içindeki bakır miktarı ve anot çamurunun ihtiva ettiği diğer elementlerin oranları $(\mathrm{Pb}, \mathrm{Sn}$, $\mathrm{Ba}, \mathrm{Ni}, \mathrm{Zn}$, Se ve Te) ICP-OES cihazı ile tespit edilirken her bir analizde 3 değer alınmış ve geri kazanım oranı hesaplanırken bu değerlerin ortalaması kullanılmıştır. Metal geri kazanımı değerleri Eşitlik 1 kullanılarak hesaplanmıştır.

$$
\%_{\text {Liç verimi }}=\left(C^{*} V * S F\right) /(m x w)
$$

Burada C: ICP-OES analizinden elde edilen değerlerin ortalaması (mg/L), V: liç sonrası elde edilen çözeltinin hacmi (L), SF: ICP-OES analizi öncesi yapılan seyreltme miktarı, m: liç deneylerinde kullanılan anot çamurunun ağırlığ (g), w: Anot çamurunun ihtiva ettiği elementlerin ağırlıkça oranlarıdır (mg/g).

\subsection{Optimizasyon Yöntemi}

Bu çalışmada bakır anot çamurundan bakır liçi için optimum parametrelerin belirlenmesi amaciyla Taguchi yöntemi kullanılmıştır. Taguchi yöntemi, yüksek kalitede düşük maliyetli ürün üretmek için kullanılan önemli bir deney tasarım metodudur [28,29]. Liç çalışmalarında cevher veya atıklardan metal geri kazanımını etkileyen çözücü konsantrasyonu ve bileşimi, liç sıcaklığı, çözücü ve cevher temas süresi, cevher/çözücü oranı, liç çözeltisinin $\mathrm{pH}$ değeri, cevher veya atıkların tane boyutu gibi birçok parametre vardır [30]. Deney süreçlerinin etkileyen birçok parametre olduğu durumlarda her bir parametrenin her bir seviyesini içeren tüm kombinasyonlar için oldukça fazla deneysel çalışma yapılması gereken durumlarda, Taguchi yöntemi kullanarak çok daha az sayıda deneysel çalışma ile sonuca ulaşmak mümkündür. 
Taguchi yöntemi, çok fazla deney yapılmasını gereken durumlar için kendine özgü ortogonal diziler kullanarak geleneksel yöntemden farklı olarak parametre kademelerini teker teker değiştirmek yerine eş zamanlı olarak değiştirme yapmayı önermektedir [31]. Bu çalışmada bakır anot çamurundan bakır liçi için yapılacak olan deneyler için Çizelge 1'de verilen 3 parametre ve 3 seviye için L9 ortogonal deney düzeneği seçilmiştir.

Taguchi yönteminde ortogonal deney düzeneği takip edilerek yapılan deneyler sonucu elde edilen sonuçlar bir dizi eşitlik yardımıyla Sinyal/Gürültü (Signal/Noise, S/N) oranına çevrilerek analiz değişkeni ya da performans istatistiği olarak değerlendirilmektedir. Taguchi, değişkenliği en aza indirmek için deney tasarımda performans kriteri olarak Sinyal/Gürültü oranı değerlerini tanımlamıştır [32]. İncelenen probleme bağlı olarak kullanılabilecek çok sayıda performans istatistiği geliştirildiği bildirilmektedir. Sıklıkla kullanılan performans istatistiği formülleri Eşitlik 2-4'de verilmektedir;

En büyük en iyi için,

$$
\left(\frac{S}{N}\right)_{L}=-10 * \log \left(\frac{1}{n} \sum_{i=1}^{n} \frac{1}{y_{i}^{2}}\right)
$$

En küçük en iyi için,

$$
\left(\frac{S}{N}\right)_{S}=-10 * \log \left(\frac{1}{n} \sum_{n=1}^{n} y_{i}^{2}\right)
$$

Nominal en iyi için,

$$
\left(\frac{S}{N}\right)_{N}=10 * \log \left(\frac{y^{2}}{s^{2}}\right)
$$

Burada $\mathrm{SN}_{\mathrm{L}}$ ve $\mathrm{SN}_{\mathrm{S}}$; performans istatistikleri, $\mathrm{n}$ : tekrar edilen deney sayısı, y: geri kazanılan yüzdece metal miktarıdır. Eğer metal geri kazanımı en büyük değer için optimize edilecekse $\mathrm{SN}_{\mathrm{L}}$ performans istatistik değeri kullanılır. $\mathrm{Bu}$ çalışmada bakır metali için en yüksek geri kazanım oranı amaçlandığından, her deneyin sonunda metal geri kazanım değerlerini hesaplamak için "en büyük en iyi” performans istatistiği kullanılmıştır.

Taguchi optimizasyon yönteminin en önemli adımlarından biri belirlenen optimum şartlarda elde edilecek sonucu tahmin etmek ve bu sonucu doğrulamaktır. $\mathrm{Bu}$ durumda optimum koşuldaki sonucu hesaplamak için Eşitlik 5 kullanılır [33]:

$\left(\frac{S}{N}\right)_{\text {Tahmini }}=\left[\frac{S}{N}\right]_{m}+\sum_{n=1}^{n}\left(\left[\frac{S}{N}\right]_{i}+\left[\frac{S}{N}\right]_{m}\right)$

Burada $[\mathrm{S} / \mathrm{N}]_{\mathrm{m}}$ tüm deneylerin $[\mathrm{S} / \mathrm{N}]_{\mathrm{L}}$ değerlerinin aritmetik ortalaması, $[\mathrm{S} / \mathrm{N}]_{\mathrm{i}}$ incelenen her bir parametrenin optimum seviyesindeki $[\mathrm{S} / \mathrm{N}]_{\mathrm{L}}$ değerlerinin aritmetik ortalamasıdır.

\section{BULGULAR VE TARTIŞMA}

\subsection{Bakır anot çamurunun karakterizasyonu}

Liç deneylerinde kullanılan anot çamurunun kimyasal analizi ICP-MS ve kupelasyon yöntemi ile mineralojik yapısı ise önceki çalışmalarımızda belirtildiği üzere $[14,15]$ XRD ve FE-SEM cihazları yardımıyla belirlenmiştir. Anot çamurun kimyasal kompozisyonu ve ihtiva ettiği mineralojik yapılar Çizelge 2' de gösterilmektedir.

Çizelge 2'den anlaşıldığı üzere bakır anot çamuru önemli ölçüde bakır, kalay ve kurşun elementlerinden oluşmaktadır. $\mathrm{Bu}$ elementlerin yanı sıra liç deneylerinde kullanılan bakır anot çamurunun az miktarda baryum, kükürt, nikel, antimon, stronsiyum, çinko ve bizmut elementlerini de ihtiva ettiği tespit edilmiştir. Ayrıca çalışmalarda kullanılan bakır anot çamurunun kayda değer oranda kıymetli metal (21,9 ppm Au ve 2204,2 ppm Ag) içerdiği belirlenmiştir. Bakır anot çamurları genellikle selenyum ve tellür elementleri için birincil kaynak olarak gösterilmektedir. Liç çalışmalarında kullanılan bakır anot çamurunun 413 ppm selenyum ve 83 ppm tellür elementlerini içerdiği belirlenmiştir. 
Çizelge 2. Bakır anot çamurunun kimyasal ve mineralojik analizi

\begin{tabular}{|c|c|c|}
\hline Element & Tenör (\%) & Bileşik \\
\hline $\mathrm{Cu}$ & 23,10 & $* * \mathrm{CuO}, \mathrm{Cu}_{2} \mathrm{O}, \mathrm{CuS}, \mathrm{CuSe}_{2}$ \\
\hline $\mathrm{Pb}$ & 20,51 & $* * \mathrm{PbSO}_{4}$ \\
\hline Sn & 15,42 & $* * \mathrm{SnO}_{2}$ \\
\hline $\mathrm{Ba}$ & 5,87 & $* * \mathrm{BaSO}_{4}$ \\
\hline $\mathrm{S}$ & 4,11 & \\
\hline $\mathrm{Ni}$ & 0,82 & $* * \mathrm{NiO}$ \\
\hline $\mathrm{Sb}$ & 0,24 & $* * \mathrm{SbAsO}_{4}$ \\
\hline $\mathrm{Sr}$ & 0,14 & \\
\hline $\mathrm{Zn}$ & 0,13 & $* * * \mathrm{ZnO}$ \\
\hline $\mathrm{Bi}$ & 0,11 & $* * * \mathrm{Bi}_{2} \mathrm{O}_{3} / \mathrm{BiAsO}_{4}$ \\
\hline $\mathrm{Ag}^{*}$ & 2204,2 & *** $\mathrm{Ag}_{2} \mathrm{SO}_{4}, \mathrm{Ag}_{2} \mathrm{Se}, \mathrm{Ag}_{2} \mathrm{Te}, \mathrm{CuAgSe}, \mathrm{AgCl},(\mathrm{Ag} / \mathrm{Au}) \mathrm{Te}_{2}, \mathrm{Ag}_{2} \mathrm{~S}, \mathrm{Ag}_{2} \mathrm{O}$ \\
\hline $\mathrm{Se}^{*}$ & 413 & $* * * \mathrm{Ag}_{2} \mathrm{Se}, \mathrm{Cu}_{2} \mathrm{Se}, \mathrm{CuAgSe}, \mathrm{Se}$ \\
\hline $\mathrm{Te}^{*}$ & 83 & $* * * \mathrm{Ag}_{2} \mathrm{Te}, \mathrm{Cu}_{2} \mathrm{Te},(\mathrm{Ag} / \mathrm{Au}) \mathrm{Te}_{2}, \mathrm{Te}$ \\
\hline $\mathrm{Au}^{*}$ & 21,9 & $* * * \mathrm{Au},(\mathrm{Ag} / \mathrm{Au}) \mathrm{Te}_{2}$ \\
\hline \multicolumn{3}{|c|}{$\begin{array}{l}\text { * } \quad \text { Anot çamuru bünyesindeki miktarları ppm seviyesindedir. } \\
\text { ** XRD analizi ile tespit edilen yapılar }[14,15] \\
\text { *** Anot çamuru bu bünyesindeki muhtemel fazlar [34] }\end{array}$} \\
\hline
\end{tabular}

Li ve arkadaşları [34] yaptıkları bir çalışma ile dünya genelinde farklı rafinerilerde ortaya çıkan bakır anot çamurlarının farklı kimyasal yapılar gösterdiğini belirtmişlerdir. $\mathrm{Bu}$ çalışmada araştırmacılar, bakır anot çamurlarının elementel olarak \%7-53 aralığında bakır, \%0,016-1,04 aralığında altın, \%0,22-22,25 aralığında gümüş elementi içerebileceğini ifade etmişlerdir. $\mathrm{Bu}$ çalışmada kullanılan bakır anot çamurunun kimyasal kompozisyonu farklı rafinerilerde ortaya çıkan diğer bakır anot çamurları ile karşılaştırıldığında altın ve gümüş gibi kıymetli metallerin önceki çalışmalarda belirtilen oranlara göre oldukça az olduğu yapılan kimyasal analiz ile ortaya konmuştur. Bu durumun temel sebebi, anot çamurunun temin edildiği bakır üretim tesisinde çoğunlukla daha önce rafine edilmiş hurda bakır malzemelerinin ham madde olarak kullanılmasıyla açıklanabilir.

Bu çalışmada kullanılan bakır anot çamurunun ana $\begin{array}{lllll}\text { yapısını } & \mathrm{PbSO}_{4} & \text { ve } & \mathrm{SnO}_{2} & \text { bileşikleri }\end{array}$ oluşturmaktadır. $\mathrm{Bu}$ yapılarla birlikte bakır anot çamurunun içerisinde bakır $\mathrm{CuO}, \mathrm{Cu}_{2} \mathrm{O}$ ve $\mathrm{CuSe}_{2}$ şeklinde bulunmaktadır. Ayrıca, bakır anot çamuru içerisinde $\mathrm{BaSO}_{4}$ ve $\mathrm{SbAsO}_{4}$ bileşiklerinin bulunduğu da tespit edilmiştir. Anot çamurunun ihtiva ettiği bilinen altın, gümüş, selenyum ve tellür metalleri ve bu metallerin diğer elementlerle oluşturduğu bileşikler düşük miktarları nedeniyle XRD analizi ile tespit edilememiştir. $\mathrm{Li}$ ve arkadaşlarının [34] yaptıkları çalışmaya göre anot çamurunun ihtiva ettiği kıymeti metallerin olas1 bileşikleri Çizelge 2'de gösterilmiştir.

Bakır anot çamurunun detaylı mineralojik analizi alan emisyon taramalı elektron mikroskobu (FESEM) cihaz yardımıyla gerçekleştirilmiştir. Anot çamuru her hangi bir kaplama yapılmaksızın enerji dağılımlı spektroskopi (EDS) ile donatılmış SEM cihazı ile analiz edilmiştir. SEM analizinde renkli haritalama yöntemi kullanılmış ve anot çamurunun ihtiva ettiği ana elementler farklı renklere temsil edilmiştir. Elementel haritalama yönteminde oksijen mavi, kalay turuncu, bakır kırmızı, baryum beyaz, nikel koyu yeşil, kükürt sarı ve çinko mor renk ile gösterilmiştir. Anot çamurunun seçili alanı için SEM görüntüsü ve elementel haritalama analizinin sonucu Şekil 2'de verilmiştir. 


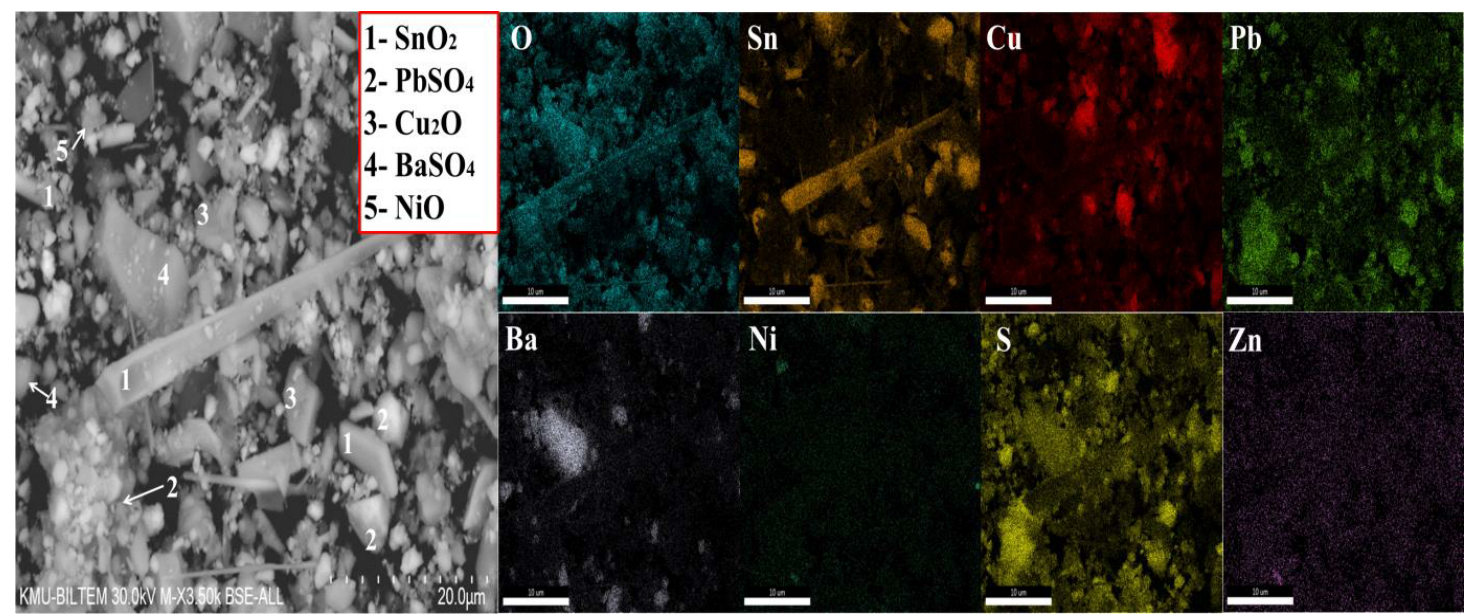

Şekil 2. Bakır anot çamurunun seçili alanı için SEM görüntüsü

Şekil 2'de verilen bakır anot çamurunun seçili alanı için SEM görüntüsü incelendiğinde, bakır anot çamurunun hem şekil hem de boyut olarak homojen bir yapıda olmadığı tespit edilmiştir. Bakır anot çamurunun içerdiği ağırlıkça fazla olan elementlerin $(\mathrm{Cu}, \mathrm{Pb}, \mathrm{Sn}$ ve $\mathrm{O})$ numune içerisinde homojen ve farklı şekillerde dağıldığı tespit edilmiştir. Bunun yanı sıra miktarca daha az olan baryum ve nikel elementleri seçili alan içerisinde farklı noktalarda bileşikler oluşturmuşlardır. Bakır anot çamurunun sahip olduğu ana fazlardan $\mathrm{SnO}_{2}$ iğnemsi bir yapıda olduğu diğer ana fazların ise farklı boyut ve şekillerde olduğu SEM analizi ile tespit edilmiştir.

\subsection{Düşük Ötektik Noktalı Çözücü ile Yapılan Liç Çalışmaları}

Bakır anot çamurundan ChCl-üre (DES) kullanılarak yapılan deneyler sonrasında bakırın çözeltiye alma oranları, elde edilen metal yüklü liç çözeltisindeki bakır miktarının ICP-OES cihazı ile tespit edilmesi sonrası Eşitlik 1 kullanarak hesaplanmıştır. Bakır anot çamurundan bakır çözeltiye alınması için yapılan deneylerden sonra elde edilen liç verimi oranları ve en büyük en iyi performans istatistik değerleri $\left(\mathrm{S} / \mathrm{N}_{\mathrm{L}}\right)$ Çizelge 3'de gösterilmektedir.

Çizelge 3. DES kullanılarak gerçekleştirilen bakır liçinde takip edilen L9 deney düzeneği, bakırın çözeltiye alınma oranları ve performans istatistik değerleri

\begin{tabular}{|c|c|c|c|c|c|}
\hline \multirow{2}{*}{$\begin{array}{l}\text { Deney } \\
\text { No }\end{array}$} & \multicolumn{3}{|c|}{ Parametre ve Seviyeleri } & \multirow{2}{*}{$\begin{array}{c}\text { Bakır Geri Kazanımı } \\
(\%)\end{array}$} & \multirow[b]{2}{*}[\mathrm{S}/\mathrm{N}]{$_{\mathrm{L}}$} \\
\hline & $\begin{array}{c}\text { Liç Sıcaklığ } 1 \\
\left({ }^{\circ} \mathrm{C}\right)\end{array}$ & $\begin{array}{l}\text { Liç Süresi } \\
\text { (saat) }\end{array}$ & $\begin{array}{c}\text { Kat1/S1v1 Oran1 } \\
(\mathrm{g} / \mathrm{mL})\end{array}$ & & \\
\hline 1 & 75 & 1 & $1 / 10$ & 81,68 & 38,24 \\
\hline 2 & 75 & 2 & $1 / 15$ & 91,45 & 39,22 \\
\hline 3 & 75 & 4 & $1 / 20$ & 87,82 & 38,87 \\
\hline 4 & 85 & 1 & $1 / 15$ & 85,14 & 38,60 \\
\hline 5 & 85 & 2 & $1 / 20$ & 94,15 & 39,47 \\
\hline 6 & 85 & 4 & $1 / 10$ & 93,76 & 39,44 \\
\hline 7 & 95 & 1 & $1 / 20$ & 89,82 & 39,06 \\
\hline 8 & 95 & 2 & $1 / 10$ & 95,58 & 39,60 \\
\hline 9 & 95 & 4 & $1 / 15$ & 95,24 & 39,57 \\
\hline
\end{tabular}


Yapılan analizler sonrası elde edilen sonuçlar kullanarak her bir parametre için performans istatistik grafikleri Minitab 17 programı kullanarak çizilmiştir. ChCl-üre kullanılarak anot çamurundan bakırın çözeltiye alınması için incelenen parametrelerin performans istatistik grafikleri Şekil 3' te gösterilmiştir.

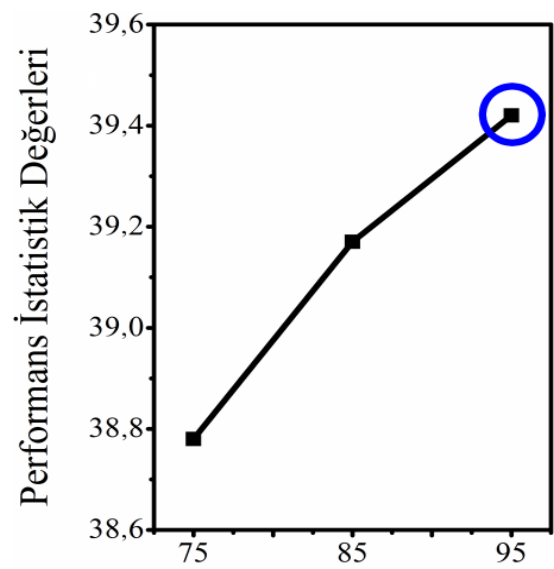

Liç Sicaklığı (oC)

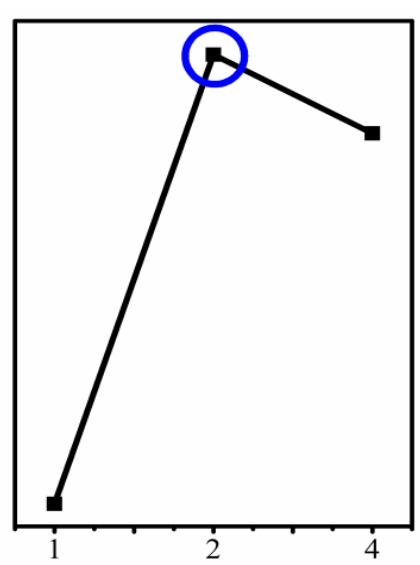

Liç Süresi (saat)

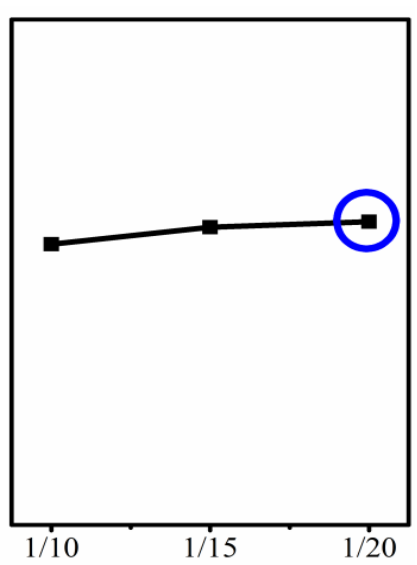

Kat1/Siv1 Oranı $(\mathrm{g} / \mathrm{L})$

Şekil 3. $\mathrm{ChCl}$ - üre kullanılarak bakır anot çamurundan bakır geri kazanımı için incelenen parametrelerin performans istatistik grafikleri

Şekil 3'de gösterilen performans istatistik grafiklerine, ChCl-üre kullanılarak anot çamurundan bakırın çözeltiye alınması için belirlenen optimum koşullar; liç sıcaklığı: $95{ }^{\circ} \mathrm{C}$, liç süresi: 2 saat ve kat1/sıv1 oran1 1/20 olarak tespit edilmiştir. $\mathrm{Bu}$ koşullar altında $\mathrm{ChCl}$-üre ile bakır anot çamurundan tahmini bakır liç verimi Eşitlik 5 kullanılarak hesaplanmıştır. Bu deneyler sonucunda bakırın çözeltiye alınması için belirlenen optimum koşullar, tahmini bakır liç verimi ve doğrulama deneyinin sonuçları Çizelge 4'de gösterilmektedir.

Çizelge 4. ChCl-üre kullanılarak elde edilen bakırın çözeltiye alınması için optimum koşullar, tahmini hesaplama ve doğrulama deneyinden elde edilen bakır liç verimleri

\begin{tabular}{|l|c|c|}
\hline \multirow{2}{*}{ Parametre } & \multicolumn{2}{|c|}{ Optimum Seviye Koşulları } \\
\cline { 2 - 3 } & Değer & Seviye \\
\hline Liç Sıcaklı̆̆1 & $95^{\circ} \mathrm{C}$ & 3 \\
\hline Liç Süresi & 2 saat & 3 \\
\hline Katı/Sıv1 Oranı & $1 / 20 \mathrm{~g} / \mathrm{mL}$ & \\
\hline Tahmini bakır liç verimi & $\% 96$ & \\
\hline Doğrulama deneyinden elde edilen bakır liç verimi & $\% 98$ & \\
\hline
\end{tabular}

Çizelge 4'te görüldüğü üzere belirlenen optimum koşullar altında tahmini bakır liç verimi \%96 olarak hesaplanmış, yapılan doğrulama deneyi sonrasında ise \%98 bakır liç verimi değerli elde edilmiştir. Bu sonuçlara göre DES kullanarak optimum koşullar altında tahmin edilen bakır liç verimi değeri ile doğrulama deneyi sonrası elde 
edilen sonuç arasında iyi bir ilişki olduğu söylenebilir.

$\mathrm{Bu}$ deney sisteminde incelenen parametrelere ait performans istatistik grafikleri o parametrenin proses üzerindeki etkisini ifade etmez. Proses üzerinde hangi parametrenin en etkin olduğunu belirlemek için birçok araştırmacı [28,35] ANOVA analizine başvurmuştur. Bu yüzden, DES çözücü sistemi içerisinde anot çamurundan bakır liç verimi için ANOVA analizi yapılmıştır. ANOVA analizinin sonuçları Çizelge 5'te verilmektedir.

Çizelge 5. $\mathrm{ChCl}$ ve üre ile hazırlanan DES kullanılarak anot çamurundan yapılan bakır liçi için varyans analizi

\begin{tabular}{|l|c|c|c|c|c|}
\hline Kaynak & $\begin{array}{c}\text { Serbestlik } \\
\text { Derecesi }\end{array}$ & $\begin{array}{c}\text { Kareler } \\
\text { Toplamı }\end{array}$ & $\begin{array}{c}\text { Kareler Toplamının } \\
\text { Ortalamas1 }\end{array}$ & F- Değeri & $\begin{array}{c}\% \\
\text { Etki }\end{array}$ \\
\hline Liç Sıcaklı̆̆1 & 2 & 65,746 & 32,8730 & 9,22 & 36,50 \\
\hline Liç Süresi & 2 & 114,273 & 57,1363 & 16,02 & 63,42 \\
\hline Kat1/Sıvı Oran1 & 2 & 0,139 & 0,0695 & 0,02 & 0,08 \\
\hline Hata & 2 & 7,134 & 3,5668 & & \\
\hline Toplam & 8 & 187,291 & & & \\
\hline
\end{tabular}

Çizelge 5'de verilen ANOVA analizine göre L9 deney düzeneği ile incelenen parametreler arasında $\mathrm{ChCl}$ ve üre ile hazırlanan DES içerisinde anot çamurundan bakır liçini etkileyen en önemli parametreler \%63,42'lik oranla liç süresine ve \%36,50'lik oranla liç sıcaklığına aittir. Ayrıca, ANOVA analizinden elde edilen $\mathrm{R}^{2}$ katsayısı, modelin sistemi ne kadar iyi açıklandığı ifade eder. $\mathrm{Bu}$ durumda, ANOVA analizinden elde edilen katsayısının değeri $\left(\mathrm{R}^{2}\right) \quad 0,9619$ olarak elde edilmiştir.

Literatürde yer alan çalışmalarda [36,37] belirttiği üzere $\mathrm{ChCl}$ ve üre ile hazırlanan DES içerisindeki $\mathrm{Cl}^{-}$iyonları çözünme mekanizmasında etkili iken, $\mathrm{Ch}^{+}$iyonu çözünme mekanizmasına katılmamaktadır. Liç işlemleri sırasında $\mathrm{Cl}^{-}$ iyonları metal-oksijen bağını zayıflatarak metal merkezine ürenin sahip olduğu oksijenin bağlanması ve ürenin sıvı olarak görev yapması sonucunda metal kompleks anyonlarının $\left(M \times C l O .[u ̈ r e]^{-}\right) \quad$ oluşumu ile çözünme gerçekleşmektedir. Ayrıca, önceki çalışmalarda ifade edildiği üzere [38-40] metal bileşeninin oksitli ya da sülfürlü olmasından bağımsız olarak $\mathrm{ChCl}$ ve üre ile hazırlanan çözücü içerisinde metallerin çözünmesi sonrasında, nihai liç çözeltisi içerisinde metal kompleks anyonların oluştuğu bilinmektedir. $\mathrm{Bu}$ nedenle bakır anot çamurunun DES ile liç işleminden sonra, liç çözeltisi içerisinde [CuClO.üre] $]^{-}$kompleks anyonlarının meydana geldiği ifade edilebilir. Bu bilgilerin ışı̆̆ altında, bakır anot çamurunun ihtiva ettiği bakır içerikli bileşiklerin çözünme reaksiyonları Eşitlik 6 ve 7'deki gibi ifade edilebilir:

$$
\begin{aligned}
& \mathrm{CuO}+\mathrm{ChCl} / \text { üre } \rightarrow[\mathrm{CuClO} . \text { üre }]^{-}+\mathrm{Ch}^{+} \\
& \mathrm{Cu}_{2} \mathrm{O}+\mathrm{ChCl} / \text { üre } \rightarrow\left[\mathrm{Cu}_{2} \mathrm{ClO} . \text { üre }\right]^{-}+\mathrm{Ch}^{+}
\end{aligned}
$$

Derin ötektik noktalı çözücüler ile yapılan liç işlemleri sonrasında liç çözeltisinde nihai ürün olarak $\mathrm{Cu}$-üre kompleks oluşmaktadır. Oluşan bu kompleks iyonların sividan metal kazanım proseslerini engellemediği ve elektokazanım, sementasyon ve solvent ekstraksiyon gibi sıvidan metal kazanım proseslerinin uygulanabileceği ifade edilmiştir [21,37].

Son yıllarda, bakır anot çamurlarından bakırı liç çözeltisine almak için farklı piro-hidrometalurjik yöntemler ve liç reaktifleri kullanılmıştır. Çizelge 6'da bakırın anot çamurlarından çözeltiye alınması için kullanılan yöntemlerin düşük ötektik noktalı çözücüler ile kıyaslaması verilmektedir. 
Çizelge 6. Farklı yöntemlerle bakır anot çamurlarından bakır liç verimleri

\begin{tabular}{|l|c|c|}
\hline Liç Reaktifi & Bakır Geri Kazanımı (\%) & Referans \\
\hline Kavurma \& $\mathrm{H}_{2} \mathrm{SO}_{4}$ Liçi & 99,67 & 41 \\
\hline $\mathrm{NaOH} \& \mathrm{H}_{2} \mathrm{SO}_{4}$ Liçi & 95 & 42 \\
\hline $\mathrm{HCl}_{2} \mathrm{H}_{2} \mathrm{O}_{2}$ & 100 & 43 \\
\hline $\mathrm{HNO}_{3}$ & 97 & 8 \\
\hline 1-bütil-3-metil imidazolyum hidrojen sülfat & 87,52 & 15 \\
\hline 1-etil-3-metil imidazolyum hidrojen sülfat & 50,16 & 44 \\
\hline Ultrason destekli $\mathrm{H}_{2} \mathrm{SO}_{4}$ Liçi & 99 & 45 \\
\hline Düşük Erime Noktalı Çözücü & 98 & Mevcut çalışma \\
\hline
\end{tabular}

Çizelge 6'da görüldüğü üzere, bakır anot çamurlarından bakır liçi için çoğunlukla asit liçi kullanılmıştır. Bu çalışmalarda bakır geri kazanım değerleri her ne kadar yüksek olsa da, çok miktarda asit kullanımı, liç işlemlerinde ilave ekipman kullanılması ve asitlerin doğada doğrudan kullanımları meydana gelecek çevresel zararlardan ötürü dezavantajları bulunmaktadır. Ayrıca yenilikçi çözücü olarak kullanılan imidazolyum kökenli iyonik sıvıların maliyeti nedeniyle bakır liçinde kullanımları kısıtlanmaktadır. DES ile yapılan bu çalışmada, yüksek oranda bakır liç verimi elde edilmesi ve DES'lerin maliyetlerinin az olması, ihmal edilebilir buhar basıncı, tutuşmamazlık, liç ekipmanlarında korozyona sebep olmamaları ve bakteriler tarafindan parçalanabilir (biyolojik olarak parçalanabilme) olmaları gibi çevre ve insan sağlığına karşı olumlu özelliklerinden ötürü bakır anot çamurlarından bakırın çözündürülmesi için uygun çözelti olarak düşünülebilir. Kolin klorür ve üre ile hazırlanan DES'in sağladığı avantajlarla birlikte bu karışımın sülfürik asite $\left(26,7 \mathrm{cP}, 25{ }^{\circ} \mathrm{C}\right)$ nazaran sahip olduğu yüksek vizkositesi $\left(\begin{array}{lllll}750 & \mathrm{cP}, & 25 & { }^{\circ} \mathrm{C}\end{array}\right)$ hidrometalurji çalışmalarında dezavantaj sağlamaktadır. Bu dezavantajın giderilmesi için liç işlemlerinden sonra yapılan katı-sıvı ayrımının sicak bir ortamda yapılması gerekmektedir. Bununla birlikte daha düşük viskoziteye sahip düşük erime noktalı çözücülerin bakır veya diğer değerli metallerin eldesinde kullanımları araştırılabilir.

\subsection{Liç Atığının Karakterizasyonu}

Bakır anot çamurundan bakırın çözeltiye alınması için belirlenen optimum şartlar $\left(95^{\circ} \mathrm{C}, 2\right.$ saat,
$1 / 20 \mathrm{~g} / \mathrm{mL}$ ) altında DES ile yapılan liç deneyi sonrası elde edilen liç atığının kimyasal ve mineralojik analizi SEM/EDS analizi ile gerçekleştirilmiştir. Liç deneylerinde kullanılan anot çamurunun ve optimum şartlar altında yapılan liç deneyinden sonra elde edilen liç atığının SEM/EDS analizi Şekil 4'de verilmiştir.

Liç atığının ve bakır anot çamurunun SEM/EDS analizine göre (Şekil 4) çalışmalarda kullanılan bakır anot çamurunun seçili alan için SEM/EDS analizi incelendiğinde, numuneye ait EDS analizi bölgesel olarak değişiklik göstermesi muhtemel olsa bile ICP-MS ve kupelasyon yöntemleri ile belirlenen bakır anot çamurunun kimyasal analizi ile uyum göstermektedir. Şekil 4.b'de optimum şartlar altında yapılan doğrulama deneyinden sonra elde edilen liç atığının SEM/EDS analizine göre, liç atığ 1 içerisinde $\mathrm{Sn}$, Ni ve Ba elementlerinin ağırlıkça oranlarının arttığı gözlemlenmiştir. Buna ek olarak başlangıçta iğnemsi yapıya sahip olan $\mathrm{SnO}_{2}$ 'nin ise şekil olarak değişikliğe uğramadığ 1 tespit edilmiştir. $\mathrm{Bu}$ durumun elementlerin ve oluşturdukları fazların DES içerisinde çözünmediği ya da çok az çözünürlüğe sahip olduğunu göstermektedir. Bununla birlikte bakır anot çamurunun ana yapısını oluşturan bakır ve kurşun elementlerinin ağırlıkça oranları sırasıyla $\% 23,08$ oranından $\% 2,27$ oranına ve $\% 16,49$ oranından \%3,93 oranına düştüğü gözlemlenmiştir. $\mathrm{Bu}$ sonuç DES içerisinde bakır ile birlikte kurşun elementinin sahip olduğu $\mathrm{PbSO}_{4}$ yapısının da oldukça yüksek miktarda çözündüğünü göstermektedir.

Bakır anot çamurunun ihtiva ettiği diğer elementlerin DES içerisinde çözünürlükleri 
optimum şartlar altında yapılan liç deneyinden sonra elde edilen metal yüklü liç çözeltisinin ICPOES analizi sonucunda Eşitlik 1 ile hesaplanmıştır. Başlangıç numunesinde bakır gibi miktarca fazla bulunan $\mathrm{Pb}, \mathrm{Sn}$ ve $\mathrm{Ba}$ elementleri dişında az miktarda bulunan $\mathrm{Ni}$ ve $\mathrm{Zn}$ elementleri ve ppm seviyesinde bulunan $\mathrm{Au}, \mathrm{Ag}$, Se ve Te elementleri de takip edilmiştir. Anot çamurunun ihtiva ettiği elementlerin DES içerisinde çözünürlükleri Şekil 5' te gösterilmiştir.
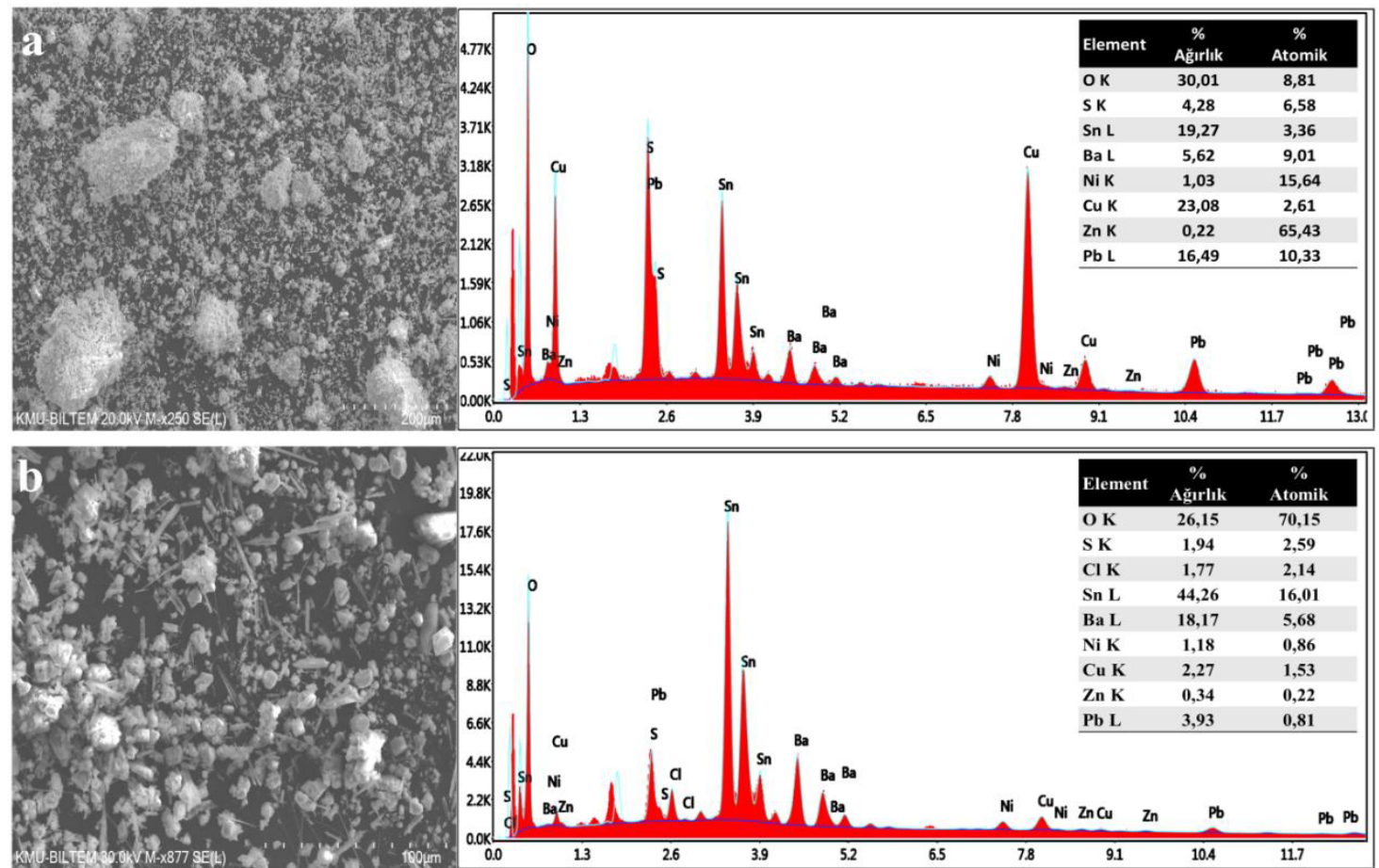

Şekil 4. a) bakır anot çamuruna ve b) liç atığına ait SEM/EDS analiz sonuçları

Şekil 5'ten anlaşılacağı üzere, bakır anot çamuru içerisinde $\mathrm{BaSO}_{4}$ olarak bulunan baryum elementinin DES içerisinde çözünürlüğü oldukça azdır (\%0.07). Optimum şartlar altında yapılan liç deneyinde bakır anot çamurunun ana elementlerinden olan nikel ve çinko elementlerinin çözünürlük oranları sırasıyla \%21 ve \%47 olarak belirlenmiştir. Numune içerisinde ppm seviyesinde bulunan selenyum ve tellür elementlerinin çözünürlük oranları sırasıyla \%20 ve \%65,6 olarak tespit edilmiștir. Bakır anot çamurunun ana yapısını oluşturan kalay DES içerisinde çözünmezken, kurşun ve bakır elementlerinin çözünürlük oranları sırasıyla \%93 ve \%98 olarak hesaplanmıştır. Ayrıca, DES ile liç işlemlerinin sonucunda elde edilen liç çözeltisinin ICP-OES cihazı yardımıyla yapılan analizlerde altın ve gümüş elementleri belirlenememiş olup tayin sınırlarının altında kalmıştır.

Önceki çalışmalarda belirtildiği üzere farklı bileşenlerle hazırlan DES'lerin farklı metal oksitleri çözebildikleri ifade edilmiştir $[19,20]$. Yapılan bu çalışmada bakır anot çamurundan bakırın çözeltiye alınması hedeflenmiş olsa da bakır anot çamurunun ihtiva ettiği diğer bazı elementlerin de çözeltiye geçtiği tespit edilmiştir. Literatürde yer alan çalıșmalara göre $[20,40]$ $\mathrm{Cu}_{2} \mathrm{O}, \mathrm{CuO}, \mathrm{PbO}_{2}$ ve $\mathrm{PbSO}_{4}$ bileşiklerinin $\mathrm{ChCl}$ ve üre ile hazırlanan DES içerinde oldukça yüksek çözünürlüğe, $\mathrm{NiO}$ bileşiğinin ise daha az çözünürlüğe sahip olduğu belirtilmiştir. Çalışma sonucunda anot çamurunun ihtiva ettiği elementlerin çözeltiye geçme oranlarının literatür ile uyumlu olduğu görülmektedir. 
Yukarıdaki deneysel verilerin 1 şı ğı altında, DES liçi bakır ve kurşun endüstrisi için etkili bir proses olarak kullanılabilir. Birçok süreçte olduğu gibi, metal çıkarım işlemlerinden sonra DES'lerin geri dönüşümü ve yeniden kullanımı proses ekonomisi için oldukça önemlidir. Literatürde bulunan bir çalışmada [46], DES'lerin oluşumunun kimyasal reaksiyonlar içermediğinden ve sadece bileşenler arasında meydana gelen hidrojen bağları ile sentezlendiğinden, DES'lerin geri dönüşümünün kolay olduğu bildirilmiştir. Ayrıca DES'ler, bakır anot çamurunun bakırsızlaştırma (decopperizing) işlemi için güvenli ve ekonomik bir çözücü olarak kullanılabilir.

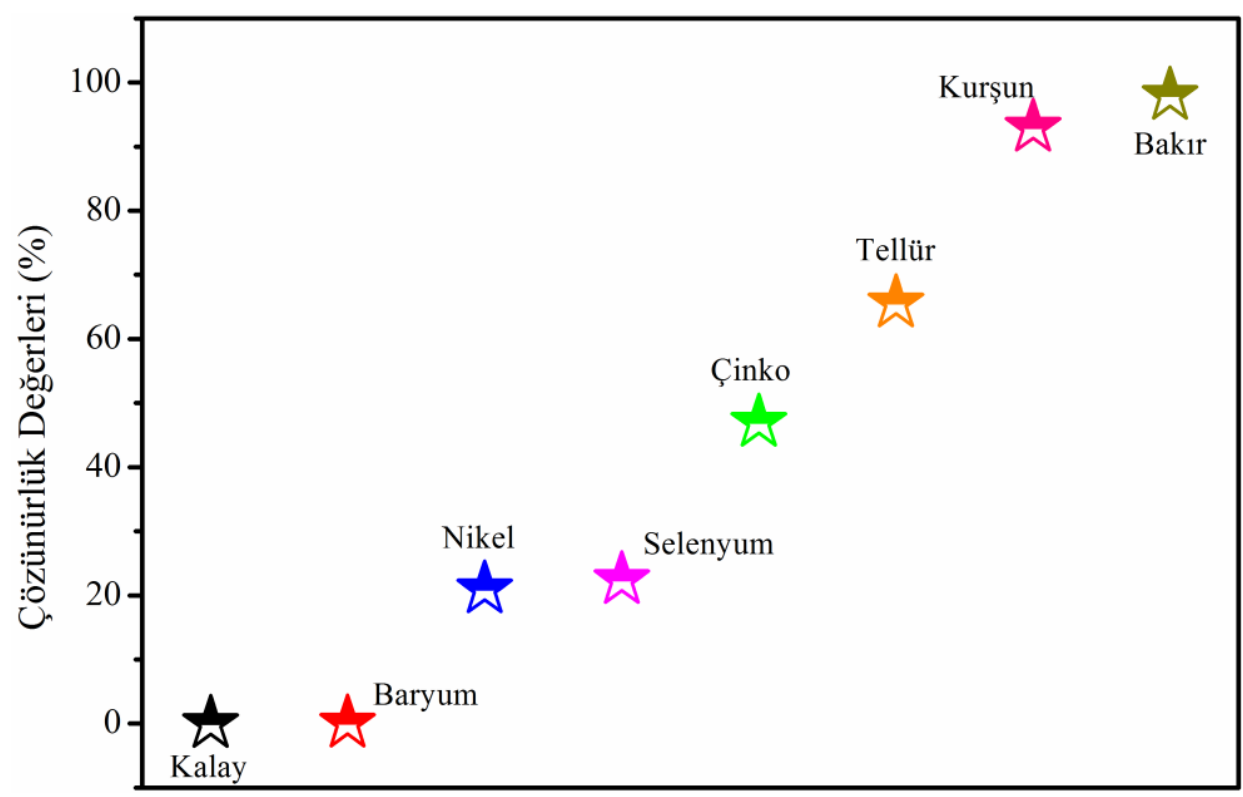

Şekil 5. Optimum şartlar altında bakır anot çamurunun ihtiva ettiği elementlerin DES içerisinde çözünürlükleri

\section{SONUÇLAR}

$\mathrm{Bu}$ çalışmada bakır anot çamurundan bakır geri kazanımı için geleneksel çözücülerin yerine düşük maliyetli, insan ve çevre sağlığına zararı olmayan düşük ötektik noktalı çözücü kullanılmıştır. Liç işlemlerinden önce yapılan kimyasal analize göre elementel olarak anot çamurunun bakır, kurşun ve kalay elementlerinden oluştuğu tespit edilmiştir. Bakır anot çamurunun mineralojik karakterizasyonuna göre $\mathrm{PbSO}_{4}$ ve $\mathrm{SnO}_{2}$ yapıları bakır anot çamurunun ana yapısını oluşturmaktadır. Bakır içerikli yapıların $\mathrm{CuO}$, $\mathrm{Cu}_{2} \mathrm{O}, \mathrm{CuS}, \mathrm{CuSe} e_{2}$ olduğu tespit edilmiştir.

Liç deneylerinde kullanılan liç reaktifi kolin klorür ve üre bileșenlerinin 1:2 molar oranda karıştırılmasıyla elde edilmiştir. Hazırlanan bu DES ile yapılan liç işlemlerinden sonra bakır geri kazanımı için optimum deneysel koşul; $95^{\circ} \mathrm{C}$ liç sıcaklığı, 2 saat liç süresi ve $1 / 20 \mathrm{~kat} 1 / \mathrm{s} ı v 1$ oranı olarak belirlenmiştir. Optimum koşullar altında hesaplanan tahmini bakır geri kazanımı ile doğrulama deneyinden elde edilen sonuç arasında uyumlu bir sonuç yakalanmıştır ve doğrulama deneyinden sonra \%98 oranında bakır geri kazanımı sağlanmıştır. Bakır geri kazanımı yanında DES ile yapılan liç işlemlerinden sonra yüksek oranda kurşun çözünürlüğü elde edilmiştir. $\mathrm{Bu}$ çalışma, metalik bakır üretiminde ortaya çıkan ve değerli atık sınıfına giren bakır anot çamurundan düşük ötektik noktalı çözücüler ile değerlendirilmesinin mümkün olduğunu göstermektedir. Bakır anot çamurlarının düşük erime noktalı çözücü ile işlenmesinin hem ülke 
ekonomisi hem de çevre ve insan sağllğ 1 için faydalı sonuçlar ortaya çıkarması beklenmektedir.

\section{TEŞEKKÜR}

$\mathrm{Bu}$ çalışmanın yapılmasını 116M057 nolu proje numarası ile destekleyen Türkiye Bilimsel ve Teknolojik Araştırma Kurumu'na (TÜBİTAK) teşekkür ederiz.

\section{KAYNAKLAR}

1. Schlesinger, M.E., Sole, K.C., Davenport, W.G., 2011. Extractive Metallurgy of Copper. Elsevier, 472.

2. Topçu, M.A., Rüşen, A., Derin, B., 2019. Minimizing of Copper Losses to Converter Slag by a Boron Compound Addition. J Mater Res Technol 8, 6244-6252. https://doi.org/ 10.1016/j.jmrt.2019.10.018.

3. Lee, J.C., Kurniawan, K., Chung, K.W., Kim, S., 2020. Metallurgical Process for Total Recovery of all Constituent Metals from Copper Anode Slimes: A Review of Established Technologies and Current Progress. Met Mater Int. https://doi.org/10.1007/s12540-020-00716-7.

4. Dehghanpoor, M.H., Zivdar, M., Torabi, M., 2016. Extraction of Copper and Gold from Anode Slime of Sarcheshmeh Copper Complex. J South African Inst Min Metall, 116, 1153-1157. http://dx.doi.org/10.17159/ 2411-9717/2016/v116n12a9.

5. Jin, Y., Kim, J., Guillaume, B., 2016. Review of Critical Material Studies. Resour Conserv Recycl 113, 77-87. https://doi.org/10.1016/ j.resconrec.2016.06.003.

6. Hait, J., Jana, R.K., Kumar, V., Sanyal, S.K., 2002. Some Studies on Sulfuric Acid Leaching of Anode Slime with Additives. Ind Eng Chem Res 41, 6593-6599. https://doi.org/10.1021/ ie020239j.

7. Yang, H., Li, X., Tong, L., Jin, Z., Yin, L., Chen, G., 2018. Leaching Kinetics of Selenium from Copper Anode Slimes by Nitric AcidSulfuric Acid mixture. Trans Nonferrous Met Soc China 28, 186-192. https://doi.org/ 10.1016/S1003-6326(18)64652-7.
8. Li, X., Yang, H., Jin, Z., Tong, L., Xiao, F., 2017. Selenium Leaching from Copper Anode Slimes Using a Nitric Acid-Sulfuric Acid Mixture. Metallurgist 61, 348-356. https://doi.org/10.1007/s11015-017-0500-2.

9. Xiao, L., Wang, Y., Yu, Yang., Fu, G., Liu, Y., Sun, Z., Ye, S., 2019. Enhanced Selective Recovery of Selenium from Anode Slime Using $\mathrm{MnO}_{2}$ in Dilute $\mathrm{H}_{2} \mathrm{SO}_{4}$ Solution as Oxidant. J Clean Prod, 209, 494-504. https://doi.org/ 10.1016/j.jclepro.2018.10.144.

10. Tokkan, D., Kuşlu, S., Çalban, T., Çolak, S., 2013. Optimization of Silver Removal from Anode Slime by Microwave Irradiation in Ammonium Thiosulfate Solutions. Ind Eng Chem Res, 52, 9719-9725. https://doi.org/ 10.1021/ie400345g.

11. Wang, S., Cui, W., Zhang, G., Zhang, L., Peng, J., 2017. Ultrafast Ultrasound-Assisted Decopperization from Copper Anode Slime. Ultrason Sonochem, 36, 20-26. https://doi.org/ 10.1016/j.ultsonch.2016.11.013.

12. Li, D., Guo, X., Xu, Z., Xu, R., Feng, Q., 2016. Metal Values Separation from Residue Generated in Alkali Fusion-Leaching of Copper Anode Slime. Hydrometallurgy, 165, 290-294. https://doi.org/10.1016/j.hydromet. 2016.01.021

13. Guo, X., Xu, Z., Tian, Q., Li, D., 2017. Optimization on Selenium and Arsenic Conversion from Copper Anode Slime by Low-Temperature Alkali Fusion Process. J Cent South Univ, 24, 1537-1543. https:// doi.org/10.1007/s11771-017-3558-x

14. Rüşen, A., Topcu, M.A., 2017. Optimization of Gold Recovery from Copper Anode Slime by Acidic Ionic Liquid. Korean J Chem. Eng. 34, 2958-2965. https://doi.org/10.1007/s11814017-0200-4.

15. Rüşen, A., Topçu, M.A., 2018 Investigation of an Alternative Chemical Agent to Recover Valuable Metals from Anode Slime. Chem Pap 72, 2879-2891. https://doi.org/10.1007/s11696 -018-0511-X.

16. Binnemans, K., Jones, P.T., 2017. Solvometallurgy: An Emerging Branch of Extractive Metallurgy. J Sustain Metall. 3, 570-600. https://doi.org/10.1007/s40831-0170128-2. 
17. Palden, T., Regadío, M., Onghena, B., Binnemans, K., 2019. Selective Metal Recovery from Jarosite Residue by Leaching with Acid-Equilibrated Ionic Liquids and Precipitation-Stripping. ACS Sustain Chem Eng. 7, 4239-4246. https://doi.org/10.1021/ acssuschemeng.8b05938.

18.Zhang, Q., Vigier, K.D.O., Royer, S., Jerome, F., 2012. Deep Eutectic Solvents: Syntheses, Properties and Applications. Chemical Society Reviews, 41(21), 7108-7146. https://doi.org/ $10.1039 / \mathrm{C} 2 \mathrm{CS} 35178 \mathrm{~A}$.

19. Abbott, A.P., Capper, G., Davies, D.L., McKenzie, K J., Obi, S.U., 2006. Solubility of Metal Oxides in Deep Eutectic Solvents Based on Choline Chloride. Journal of Chemical \& Engineering Data, 51(4), 1280-1282.

20. Abbott, A.P., Capper, G., Davies, D.L., Shikotra, P., 2006. Processing Metal Oxides Using Ionic Liquids. Mineral Processing and Extractive Metallurgy, 115(1), 15-18.

21. Abbott, A.P., Collins, J., Dalrymple, I., Harris, C.P., Mistry, R., Qiu, F., Scheirer, J., Wise, W., 2009. Processing of Electric Arc Furnace Dust Using Deep Eutectic Solvents. Aust J Chem. 62, 341-347. https://doi.org/10.1071/CH08476.

22. Bakkar, A., Neubert, V., 2019. Recycling of Cupola Furnace Dust: Extraction and Electrodeposition of Zinc in Deep Eutectic Solvents. J Alloys Compd. 771, 424-432. https://doi.org/10.1016/j.jallcom.2018.08.246.

23. Rüşen, A., Topçu, M., 2017. Investigation of Various Metal Recoveries from Zinc Plant Leach Residue by Choline-Chloride Agent. Curr Phys Chem. 7, 273-280. https://doi.org/ 10.2174/1877946807666170808120341.

24. Rodriguez, N. R., Machiels, L., Onghena, B., Spooren, J., Binnemans, K., 2020. Selective Recovery of Zinc from Goethite Residue in the Zinc Industry Using Deep-Eutectic Solvents. Rsc Adv. 10, 7328-7335. https://doi.org/ 10.1039/D0RA00277A.

25. Peeters, N., Binnemans, K., Riaño, S., 2020. Solvometallurgical Recovery of Cobalt from Lithium-Ion Battery Cathode Materials Using Deep-eutectic Solvents. Green Chem. 22, 4210-4221. https://doi.org/10.1039/D0GC009 40G.
26. Wang, S., Zhang, Z., Lu, Z.G., Xu, Z.A., 2020. Novel Method for Screening Deep Eutectic Solvent to Recycle Cathode of Li-Ion Batteries. Green Chem. 22, 4473-4482. https://doi.org/ 10.1039/D0GC00701C.

27. Abbott, A.P., Capper, G., Davies, D.L., Rasheed, R.K., Shikotra, P., 2005. Selective Extraction of Metals from Mixed Oxide Matrixes Using Choline-Based Ionic Liquids. Inorg Chem. 44, 6497-6499. https://doi.org/ 10.1021/ic0505450.

28. Khoei, A.R., Masters, I., Gethin, D.T., 2002. Design Optimisation of Aluminium Recycling Processes Using Taguchi Technique. J Mater Process Technol. 127, 96-106. https://doi.org/ 10.1016/S0924-0136(02)00273-X.

29. Taguchi, G., 2005. Chowdhury, S., Wu, Y. Taguchi's Quality Engineering Handbook. Wiley, 1696.

30. Guo, Z.H., Pan, F.K., Xiao, X.Y., Zhang, L., Jiang, K.Q., 2010. Optimization of Brine Leaching of Metals from Hydrometallurgical Residue. Trans Nonferrous Met Soc China, 20, 2000-2005. https://doi.org/10.1016/S10036326(09)60408-8.

31. Dhawan, N., Safarzadeh, M.S., Birinci, M., 2011. Kinetics of Hydrochloric Acid Leaching of Smithsonite. Russ J Non-Ferrous Met. 52, 209-216. https://doi.org/10.3103/S1067821211 030059.

32. Farahmand, F., Moradkhani, D., Safarzadeh, M. S., Rashchi, F., 2009. Brine Leaching of Lead-Bearing Zinc Plant Residues: Process Optimization Using Orthogonal Array Design Methodology. Hydrometallurgy, 95, 316-324. https://doi.org/10.1016/j.hydromet.2008.07.012.

33. Kim, S.M., Park, K.S., Do Kim, K., Park, S. D., Kim, H.T., 2009. Optimization of Parameters for the Synthesis of Bimodal Ag Nanoparticles by Taguchi Method. J Ind Eng Chem. 15, 894-897. https://doi.org/10.1016/ j.jiec.2009.09.019.

34. Liu, G., Wu, Y., Tang, A., Li, B., 2020. Recovery of Scattered and Precious Metals from Copper Anode Slime by Hydrometallurgy: A Review. Hydrometallurgy, 197, 105460-105476. https://doi.org/10.1016/ j.hydromet.2020.105460. 
35. Pérez, K., Toro, M., Saldaña, M., Rodriguez, E. S., Robles, P., Torres, D., Ricardo, I.J., 2020. Statistical Study for Leaching of Covellite in a Chloride Media. Metals. 10, 477. https:// doi.org/10.3390/met10040477.

36. Abbott, A.P., Capper, G., Davies, D.L., Shikotra, P., 2006. Processing Metal Oxides Using Ionic Liquids. Miner Process Extr Metall, 115, 15-18. https://doi.org/10.1179/ 174328506 X91293.

37. Bakkar, A., 2014. Recycling of Electric Arc Furnace Dust Through Dissolution in Deep Eutectic Ionic Liquids and Electrowinning. J Hazard Mater, 280, 191-199. https://doi.org/ 10.1016/j.jhazmat.2014.07.066.

38. Xie, X., Zou, X., Lu, X., Zheng, K., Cheng, H., Xu, Q., Zhou, Z., 2016. Voltammetric Study and Eectrodeposition of $\mathrm{Cu}$ from $\mathrm{CuO}$ in Deep Eutectic Solvents. J Electrochem Soc. 163, 537-543. https://doi.org/10.1149/2.1241609jes.

39. Rao, S., Zou, X., Wang, S. Lu, Y., Shi, T., Hsu, H., Xu, Q., Lu, X., 2019. Electrodeposition of $\mathrm{Ni}-\mathrm{Cu}$ Alloy Films from Nickel Matte in Deep Eutectic Solvent. Mater Chem Phys, 232, 6-15. https://doi.org/10.1016/j.matchemphys.2019.04 .052 .

40. Yang, H., Reddy, R.G., 2014. Fundamental Studies on Electrochemical Deposition of Lead from Lead Oxide in 2: 1 Urea/Choline Chloride Ionic Liquids. J Electrochem Soc, 161, 586. https://doi.org/10.1149/2.1161410jes.

41. Dönmez, B., Çelik, C., Çolak, S., Yartaşı, A., 1998. Dissolution Optimization of Copper from Anode Slime in $\mathrm{H}_{2} \mathrm{SO}_{4}$ Solutions. Ind Eng Chem Res, 37, 3382-3387. https://doi.org/ 10.1021/ie9800290.

42. Liu, W., Yang, T., Zhang, D., Chen, L., Liu, Y. 2014. Pretreatment of Copper Anode Slime with Alkaline Pressure Oxidative Leaching. Int J Miner Process, 128, 48-54. https://doi.org/ 10.1016/j.minpro.2014.03.002.

43. Xing, W.D., Lee, M.S., 2017. Leaching of Gold and Silver from Anode Slime with a Mixture of Hydrochloric Acid and Oxidizing Agents. Geosystem Eng, 20, 216-223. https://doi.org/10.1080/12269328.2017.127872 8.

44. Rüşen, A., Topçu, M.A., 2017. The Effect of $\mathrm{EmimHSO}_{4}$ (1-Ethyl-3-Methyl-imidazolium
Hydrogen Sulfate) on Copper Recovery from Anode Slime. AKU J Sci Eng, 17, 696-703. https://doi: 10.5578/fmbd.58610.

45. Ma, Z., Yang, H., Huang, S., Lu, Y., Xiong, L., 2015. Ultra-fast Microwave-assisted Leaching for the Recovery of Copper and Tellurium from Copper Anode Slime. Int J Miner Metall Mater, 22, 582-588. https://doi.org/10.1007/ s12613-015-1110-2.

46. Satlewal, A., Agrawal, R., Bhagia, S., Sangoro, J., Ragauskas, A.J., 2018. Natural Deep Eutectic Solvents for Lignocellulosic Biomass Pretreatment: Recent Developments, Challenges and Novel Opportunities. Biotechnol Adv, 36, 2030-2050. https://doi.org/ 10.1016/j.biotechadv.2018.08.009. 
